\title{
PENERAPAN MODEL PEMBELAJARAN TIPE JIGSAW DALAM MENINGKATKAN HASIL BELAJAR EKONOMI PERSERTA DIDIK KELAS XI IPS DI SMAN-2 PALANGKARAYA
}

\author{
Oleh \\ Sarinah*, Orhan** \\ Email: orhan.mpd@yahoo.com
}

\begin{abstract}
This study aims to determine the increase in learning outcomes and learning activities of students in learning Economics. The type of this research is the Kolas Action Research (PTK) with the research subject of all students in the XI IPS 4 class of SMAN-2 Palangka Raya, which amounted to 34 students. The data collection technique in this study uses tests and observations. Data analysis uses qualitative and quantitative data analysis. The results of this study indicate that: (I) Economic learning activities through the use of the Jigsaw type cooperative learning model for students of class XI IPS 4 of SMAN 2 Palangka Raya active and well categorized. (2) the use of the Type Jigsaw Cooperative learning model dpalpal to improve student learning outcomes indicated by the acquisition of an average value of 66.32 in the first cycle increased to 80.20 in the IL cycle Classical learning completeness also increased with a value of $47 \%$ in the cycle I increased to $97 \%$ in the II cycle
\end{abstract}

(C) Muhammadiyah University Palangkaraya

Keywords: Jigsaw type learning and economic learning outcomes

\begin{abstract}
ABSTRAK
Penelitian ini bertujuan untuk mengetahui peningkatan hasil belajar dan aktivitas belajar peserta didik pada pembelajaran Ekonomi. Jenis penelitian ini adalah Penelitian Tindakan Kolas (PTK) dengan subjek penelitian seluruh pesena didik kelas XI IPS 4 SMAN-2 Palangka Raya yang berjumlah 34 pesena didik. Teknik pengumpulan data dalam penelitian ini rnenggunakan tes dan observasi, Analisis data menggunakan analisis data kualitatif dan kuantitatif. Hasil penelitian ini menunjukkan bahwa: (I) Aktivitas belajar Ekonomi melalui penggunaan model pemhelajaran kooperatif tipe Jigsaw pada peserta didik kelas XI IPS 4 SMAN- 2 Palangka Raya aktif dan berkategori baik. (2) pengunaan model pemhelajaran Kooperatif Tipe Jigsaw dnpal meningkaikan hasil belajar peserta didik yang ditunjukkan dengan perolehan nilai rata-rata 66,32 pada siklus I meningkat menjadi 80,20 pada siklus II Ketuntasan belajar secara klasikal juga mengalami peningkatan dengan nilai $47 \%$ pada siklus I rneningkat menjadi $97 \%$ pada siklus II.
\end{abstract}

CUniversitas Muhammadiyah Palangkaraya

Kata Kunci: Pembelajaran tipe jigsaw dan hasil belajar Ekonomi. 


\section{PENDAHULUAN}

Pendidikan merupakan kebutuhan mendasar bagi manusia dalam rangka untuk meningkatkan suber daya manusia. Hal ini sesuai dengan tujuan pendidikan nasional sebagaimana yang tertuang dalam Undang- Undang RI Nomor 20 Pasal 3 tahun 2003 tentang Sistem Pendidikan Nasional adalah sebagai berikut:

Pendidikan nasional berfungsi mengembangkan kemampuan membentuk watak serta peradaban bangsa yang bermartabat dalam rangka mencerdaskan kehidupan bangsa bertujuan untuk berkembangnya potensi peserta didik agar menjadi manusia yang beriman dan bertakwa Kepada Tuhan Yang Maha Esa, berahlak mulia, sehat, berilmu, cakap, kreatif mandiri dan menjadi warga yang demokratis serta bertanggung jawab.

Berdasarkan amanat undangundang di atas jelaslah bahwa tugas seorang guru tidak hanya menyampaikan ilmu saja tetapi masih banyak yang harus dilakukan guru yaitu mendidik peserta didik agar menjadi manusia yang utuh, dengan demikian dapat dikatakan bahwa tugas guru adalah lebih berat seorang guru dituntut penguasaan sebagai kemampuan sebgai guru yang profesional dalam bidangnya. Kemampuan yang dimaksud adalah mulai dari cara mengajar penguasaan materi, pemilihan sebagai metode mengajar, kemampuan membuat perangkat mengajar, sikap, tauladan dan lain sebagainya. Dalam penyelenggaraan pendidikan disekolah yang melibatkan guru sebagai pendidik dengan peserta didik terjadi interaksi belajar mengajar ataupun proses pembelajaran. Pengertian belajar menurut Sagala (2009:12). Belajar adalah suatu proses dimana suatu organisme berubah perilakunya sebagai akibat dari pengalaman.

Suryono (2014:12) mengatakan bahwa, Belajar adalah suatu proses di mana suatu prilaku muncul atau berubah karena adanya respon terhadap suatu situasi.

Dari pengertian itu dapat disimpulkan bahwa semua aktivitas yang dilakukan oleh seseorang sehingga menimbulkan perubahan tingkah laku yang berbeda antara sesudah belajar dan sebelum belajar. Belajar merupakan kegiatan penting yang harus dilakukan setiap orang secara maksimal untuk dapat menguasai atau memperoleh suatu.

Dalam peroses pembelajaran ini, guru dengan sadar merencanakan kegiatan pembelajaran secara sistematis dan pedoman pada seperangkat aturan dan rencana tentang pendidikan yang disebut sebagai kurikulum. Secara bertahap kurikulum mengalami penyempurnaan yang bertujuan untuk meningkatkan mutu pendidikan yang berorientasi pada kemajuan sistem pendidikan nasional. Namun demikian menyempurnaan kurikulum tersebut tidak diimbangi dengan pelaksanaan kurikulum disekolah yang berupa peroses pembelajaran. Berdasarkan pengamatan secara nyata dilapangan di lapangan, proses pembelajaran disekolah masih banyak yang tidak melibatkan peserta didik, sehingga 
peserta didik kurang kereatif. Masih banyak para guru yang menggunakan yang menggunakan model pembelajaran yang konvensional dengan menggunakan model ceramah dimana guru sebagai pusat informasi menerangkan materi yang disampaikan oleh guru, sehingga peserta didik menjadi pasif dan tidak kreatif, karena tidak ada kesempatan bertanya, berdiskusi baik dengan guru maupun sesama peserta didik. Menurut Nanang dan Cucu (2012:41) mengatakan bahwa:

Model pembelajaran merupakan salah satu pendekatan dalam rangka mensiasati perubahan perilaku peserta didik secara adaptif maupun generatif. Model pembelajaran sangatlah erat kaitanya dengan gaya mengajar guru (teaching style). Model pembelajaran diartikan sebagai prosedur sistematis dalam mengorganisasikan pengalaman belajar untuk mencapai tujuan belajar. Dapat diartikan suatu pendekatan yang digunakan dalam keiatan pembelajaran. Jadi sebenarnya model pembelajaran memiliki arti yang sama dengan pendekatan, strategi atau model pembelajaran. Saat ini telah banyak dikembangkan berbagai macam model pembelajaran, dari yang sederhana sampai model yang kompleks dan rumit, karena memerlukan banyak alat bantu dalam penerapannya.

Sedangkan menurut Trianto (2014:22) model pembelajaran adalah suatu perencanaan atau suatu pola yang digunakan sebagai suatu pedoman dalam merencanakan pembelajaran dikelas atau pembelajaran.
Banyak guru yang masih menggunakan metode konvensional, sehingga peserta didik kurang termotivasi untukbelajar yang menyebabkan prestasi belajaranya rendah, hal ini terbukti dari banyaknya peserta didik yang remidi pada setiap ulangan harian. Untuk melaksanakan tugas ini, guru disamping harus menguasai materi atau bahan yang akan diajarkan. Juga di tuntut untuk memiliki seperangkat pengetahuan dan keterampilan teknik mengajar, mencoba berbagai macam model pembelajaran yang benar-benar tepat dan bermakna untuk menyempurnakan pelaksanaan tugas mengajarkan memperoleh hasil yang maksimal sesuai dengan yang diharapkan.

Berdasarkan hasil observasi diketahui beberapa guru, khusunya di SMAN-2 Palangka Raya sudah berusaha untuk mencapai ketuntasan, namun dengan segala keterbatasan hasilnya masih belum sampai yang diharapkan. Ini terlihat dari hasil belajar mata pelajaran Ekonomi untuk Kelas XI IPS 4 yang berjumlah 34 orang perserta didik hanya 55\%(16 orang) masih dibawah rata-rata KKM (Kriteria Ketuntasan Minimum), sedangkan kreteria ketuntasan minimal (KKM) dengan acuan keberhasil pada mata pelajaran Ekonomi SMAN 2 Palangka Raya yaitu 70. Data di atas diperoleh dari guru mata pelajaran ekonomi. Untuk mengatasi masalah tersebut, maka perlunya memilih strategi pembelajaran yang tepat, sehingga dapat meningkatkan keaktivan pemahaman serta hasil belajar Ekonomi 
peserta didik dapat berhasil dengan menggunakan Model pembelajaran kooperatif. Model pembelajaran kooperatif adalah model pembelajaran yang menggerakan peserta didik berinteraksi dengan teman-teman sebayanya secara aktif dan positif, model pembelajaran koopertif bekerja dalam sebuah kelompok yang terdiri dari tiga atau lebih anggota. Pembelajaran kooperatif merupakan bentuk pembelajaran dengan cara peserta didik belajar dan bekerja dalam kelompok-kelompok kecil secara kolaboratif yang anggotanya terdiri dari empat sampai enam orang peserta didik dengan struktur kelompok yang bersifat heterogen.Para guru terus berusaha untuk menyusun dan menerapkan berbagai strategi yang bervariasi agar peserta didik tertarik dan bersemangat dalam belajar Ekonomi.. Penggunaan model pembelajaran sangat diutamakan guna menimbulkan gairah belajar, motivasi belajar, merangsang peserta didik berperan aktif dalam proses pembelajaran. Melalui Metode Pembelajaran Kooperatif Tipe Jigsaw diharapkan dapat lebih mempermudah pemahaman materi pembelajaran yang di berikan dan nantinya mempertinggi kualitas proses pembelajaran yang selanjudnya dapat meningkatkan hasil belajar peserta didik. Menurut Anita (2007:29) mengatakan teknik jigsawdidesain untuk meningkatkan rasa tanggung jawab peserta didik terdapat pembelajaranya sendiri dan juga pembelajaran orang lain.

Sedangkan Rusman (2011:29) menyatakan bahwa:

\begin{abstract}
Model Kooperatif Jigsawini peserta didik dimiliki banyak kesempatan untuk mengemukakan pendapat dan mengolah informasi yang didapat dan dapat meningkatakan keterampilan berkomunikasi, anggota kelompok bertanggung jawab terhadap keberhasilan kelompoknya dan ketuntasan bagian materi yang dipelajari dan dapat menyampaikan informasinya kepada kelompok lain. Diharapkan dengan menggunakan Model Pembelajaran Kooperatif Tipe Jigsaw dalam peroses pembelajaran sehingga akan meningkatkan hasil belajar peserta didik.
\end{abstract}

Berdasarkan fenomena diatas maka peneliti merasa tertarik untuk melakukan penelitian dengan judul Penerapan Model Pembelajaran Kooperatif Tipe Jigsaw dalam Meningkatkan Hasil Belajar EkonomiPeserta Didik Kelas XI IPS di SMAN-2 Palangka Raya.

Adapun tujuan yang ingin dicapai dalam penelitian ini yaitu:

1. Untuk mengetahui aktivitas peserta didik Kelas XI IPS SMAN-2 Palangka Raya pada saat pembelajaran Ekonomi dengan menggunakan Model Pembelajaran Kooperatif tipe Jigsaw.

2. Untuk mengetahui peningkatan hasil belajar Ekonomi peserta didik Kelas XI IPS SMAN-2 Palangka Raya dengan menggunakan Model Pembelajaran Kooperatif Tipe Jigsaw. 


\section{METODE PENELITIAN}

Penelitian yang digunakan adalah penelitian Tindakan Kelas (PTK) yang dilakukan oleh peneliti secara langsung. Dimana penelitian tersebut langsung dalam penelitian sejak awal sampai dengan hasil penelitian berupa laporan. Dalam penelitian ini, penelitian bertindak sebagi penelitian dan pengajar.

1. Perencanaan mencakup membuat rencana pembelajaran, membuat lembar observasi.

2. Melakukan tindakan, melaksanakan semua perencanaan yang telah disusun.

3. Pengamatan, melakukan pengamatan dengan mengisi observasi.

4. Refleksi, kegiatan mengingat dan merenungkan kembali suatu tindakan yang berdasarkan catatan pengamatan.

Kusnandar (2012:46) mengatakan bahwa: Penelitian tindakan kelas dapat juga diartikan suatu kegiatan ilmiah yang dilakukan oleh guru dikelasnya sendiri dengan jalan merancang, melaksanakan, mengamati, dan merefleksikan dan partisipatif yang bertujuan untuk memperbaiki atau meningkatkan mutu proses pembelajaran dikelas.

\section{HASIL DAN PEMBAHASAN}

Pembahasan hasil penelitian memuat pengelolaan data tentang hasilpengamatan aktivitas guru dan peserta didik dan hasil pos test peserta didik.
1. Hasil Pengamatan Aktivitas Guru dan Peserta Didik

Hasil pengamatan terhadap aktifitas guru dan peserta didik dalampembelajaran Ekonomi dengan materi Badan Usaha Milik Negara yangmenggunakan model pembelajaran Kooperatif Tipe Jigsawsaat pembelajaran berlangsung dicatat oleh dua orang observer yaitu guru dan teman sebaya sebagai berikut:

Berdasarkan hasil penelitian melalui pembelajaran menggunakan model pembelajaran Kooperatif Tipe Jigsaw oleh peneliti di kelas XI IPS-4 SMAN-2 Palangka Raya aktivitas guru dan peserta didik menunjukkan perkembangan yang baik. Aktivitas guru dan peserta didik pada siklus I oleh pengamat I memperoleh nilai ratarata 3,1 dan 3,2 dan pengamat II dengan nilai rata-rata 3,3 dan 3,5 . Sedangkan pada siklus II ada peningkatan menjadi lebih baik, dengan penilaian rata- rata oleh pengamat I sebesar 3,4 dan 3,5 dan oleh pengamat II dengan nilai rata-rata 3,5 dan 3,7.

Berdasarkan hasil penelitian di atas maka pelaksanaan perbaikan aktivitas dan hasil belajar peserta didik pada materi Badan Usaha Milik Negara dengan menggunakan model pembelajaran Kooperatif Tipe Jigsaw dapat membantu meningkatkan hasil belajar peserta didik. Indikator yang menunjukkan aktivitas dan hasil belajar peserta didik dalam pembelajaran yang menjadi penilaian pengamatan guru dalam penelitian ini adalah: 
1. Aktivitas peserta didik dalam mengikuti pembelajaran indikator pencapaiannya adalah: peserta didik antusias dalam melaksanakan modelpembelajaran Kooperatif Tipe Jigsaw.

2. Hasil belajar, indikator pencapaiannya adalah: hasil belajar peserta didikmeningkat.

\section{KESIMPULAN}

Berdasarkan data hasil penelitian dan pembahasan dalam penelitiantindakan kelas (PTK) yang didapat peneliti selama penelitian di SMAN-2 Palangka Raya di kelas XI IPS-4 dapat disimpulkan sebagai berikut:

1. Aktivitas belajar perserta didik dalam pembelajaran ekonomi dengan menggunakan model Pembelajaran kooperatif Tipe Jigsaw lebih baik dengan berategori aktif di kelas XI IPS4 SMAN-2 Palangka Raya, yaitu skor aktivitas belajar perserta didik siklus I dengan sekor ratarata 3,4 dan siklus II dengan skor rata-rata 3,6 , sehingga aktivitas perserta didik pada siklus II sudah dikatan baik.

2. Ada peningkatan hasil belajar Ekonomi perserta didik setelah diajarkan dengan menggunakan model pembelajaran kooperatif tipe Jigsaw pada peserta didik kelas XI IPS-4 SMAN-2 Palangka Raya. Hal ini terlihat dari data hasil belajar perserta didik pada saat pre tes/memperoleh nilai rata-rata 53,08, post test siklus I memperoleh nilai rata-rata 66,32 dan pada siklus II meningkat dengan nilai rata-rata menjadi 80,20 .

\section{DAFTAR PUSTAKA}

Anita Lie. (2007). Cooperatif Learning. Jakarta: Grasindo

Kusnandar. (2012). Penelitian Tindakan Kelas. Jakarta: Rajawali.

Nanang. (2012). Model-Model Pembelajaran. Jakarta: PT. Bumi Aksara

Rusman. (2011). Model-Model Pembelajaran Mengembangkan Profesionalisme Guru. Jakarta: PT. Raja Grafindo Persada.

Sagala. (2009). Belajar dan Pembelajaran. Bandung: PT Remaja Rosdakarya

Trianto. (2014). Model Pembelajaran Terpadu. Jakarta: Bumi Aksara.

Undang-Undang Pendidikan No 20 Tahun 2003. Tentang Sistem Pendidikan Nasional. Jakarta: Sekretariat Negara 